\title{
Early calcium increase triggers the formation of olfactory long-term memory in honeybees
}

\author{
Emmanuel Perisse ${ }^{1,2}$, Valérie Raymond-Delpech 1,3, Isabelle Néant ${ }^{2,3}$, \\ Yukihisa Matsumoto ${ }^{1}$, Catherine Leclerc ${ }^{2,3}$, Marc Moreau ${ }^{2,3}$ and Jean- \\ Christophe Sandoz*1,3
}

\begin{abstract}
Address: ${ }^{1}$ Centre de Recherches sur la Cognition Animale (CRCA), Université de Toulouse, CNRS, Toulouse, France , ${ }^{2}$ Centre de Biologie de Développement (CBD), Université de Toulouse, CNRS, Toulouse, France and ${ }^{3}$ GDR 2688 'Role of calcium in gene expression in normal and pathological conditions'

Email: Emmanuel Perisse - eperisse@cict.fr; Valérie Raymond-Delpech - raymond@cict.fr; Isabelle Néant - neant@cict.fr;

Yukihisa Matsumoto - matsumot@cict.fr; Catherine Leclerc - leclerc@cict.fr; Marc Moreau - moreau@cict.fr; Jean-

Christophe Sandoz* - sandoz@cict.fr

* Corresponding author
\end{abstract}

Published: 16 June 2009

BMC Biology 2009, 7:30 doi:10.1186/1741-7007-7-30

This article is available from: http://www.biomedcentral.com/174I-7007/7/30

(c) 2009 Perisse et al.; licensee BioMed Central Ltd.

This is an open access article distributed under the terms of the Creative Commons Attribution License (http://creativecommons.org/licenses/by/2.0), which permits unrestricted use, distribution, and reproduction in any medium, provided the original work is properly cited.
Received: 27 January 2009

Accepted: 16 June 2009

\begin{abstract}
Background: Synaptic plasticity associated with an important wave of gene transcription and protein synthesis underlies long-term memory processes. Calcium $\left(\mathrm{Ca}^{2+}\right)$ plays an important role in a variety of neuronal functions and indirect evidence suggests that it may be involved in synaptic plasticity and in the regulation of gene expression correlated to long-term memory formation. The aim of this study was to determine whether $\mathrm{Ca}^{2+}$ is necessary and sufficient for inducing long-term memory formation. A suitable model to address this question is the Pavlovian appetitive conditioning of the proboscis extension reflex in the honeybee Apis mellifera, in which animals learn to associate an odor with a sucrose reward.
\end{abstract}

Results: By modulating the intracellular $\mathrm{Ca}^{2+}$ concentration $\left(\left[\mathrm{Ca}^{2+}\right] \mathrm{i}\right)$ in the brain, we show that: (i) blocking $\left[\mathrm{Ca}^{2+}\right] \mathrm{i}$ increase during multiple-trial conditioning selectively impairs long-term memory performance; (ii) conversely, increasing $\left[\mathrm{Ca}^{2+}\right]$ i during single-trial conditioning triggers long-term memory formation; and finally, (iii) as was the case for long-term memory produced by multipletrial conditioning, enhancement of long-term memory performance induced by a $\left[\mathrm{Ca}^{2+}\right] \mathrm{i}$ increase depends on de novo protein synthesis.

Conclusion: Altogether our data suggest that during olfactory conditioning $\mathrm{Ca}^{2+}$ is both a necessary and a sufficient signal for the formation of protein-dependent long-term memory. $\mathrm{Ca}^{2+}$ therefore appears to act as a switch between short- and long-term storage of learned information.

\section{Background}

Activity-dependent modifications of synaptic strength are thought to form a basis for the neuronal changes that are associated with the formation of long-term memory
(LTM) [1,2]. Intensive previous work has sought to unravel the molecular cascades involved in LTM formation in different animal models from vertebrates to invertebrates [3-5]. The hallmark of LTM is that it requires an 
important wave of protein synthesis $[6,7]$. The formation of LTM was also shown to depend on a number of molecular actors, such as adenylate cyclase (AC), calcium/calmodulin-dependent kinase II $\left(\mathrm{Ca}^{2+} / \mathrm{CaMKII}\right)$, cyclic adenosine monophosphate (cAMP) responsive element binding protein (CREB) factor, calcineurin and nitric oxide (NO) among others [4,8-14]. Usually, LTM is formed after multiple learning trials, so that trial repetition is thought to induce specific molecular cascades leading to the gene expression and protein synthesis necessary for LTM formation. Many efforts have been invested in finding the molecular trigger at the start of these cascades, which may thus represent the earliest event in LTM formation. However, until now, this search has remained rather inconclusive.

One possible candidate for this role is $\mathrm{Ca}^{2+}$. Indeed, most molecules shown to be involved in LTM formation depend directly or indirectly on $\mathrm{Ca}^{2+}$, usually through $\mathrm{Ca}^{2+}$-binding proteins. A highly studied example and one of the earliest actors in these cascades is $\mathrm{AC}$ $[9,12,13,15,16]$. Several studies have shown that the AC subtypes involved in LTM are activated by the $\mathrm{Ca}^{2+}$-binding protein calmodulin (CaM) $[15,17,18]$ and consequently suggest that $\mathrm{Ca}^{2+}$, and not $\mathrm{AC}$, may be the initial trigger for LTM formation. Another argument for the central role that $\mathrm{Ca}^{2+}$ may play in LTM formation is the demonstration that $\mathrm{Ca}^{2+}$ is crucial for the establishment of long-term potentiation, a well-studied cellular model thought to underlie LTM $[19,20]$. Several previous studies have made a link between $\mathrm{Ca}^{2+}$ levels and memory processing [21-25]. In these studies however, pharmacological drugs used in vivo and in vitro acted on different receptors involved in the modulation of intracellular $\mathrm{Ca}^{2+}$ concentration $\left(\left[\mathrm{Ca}^{2+}\right] \mathrm{i}\right)$ but did not act directly on $\mathrm{Ca}^{2+}$. Moreover, most studies suggested that $\mathrm{Ca}^{2+}$ is necessary for LTM formation, but they did not show that it may be sufficient; that is, that in association with a learning procedure producing only short-term memory, $\mathrm{Ca}^{2+}$ may induce LTM formation. The aim of our work is to demonstrate the direct role of $\mathrm{Ca}^{2+}$ in memory formation and to show that it is both necessary and sufficient during conditioning to induce LTM formation. Our hypothesis is that an increase in the $\left[\mathrm{Ca}^{2+}\right] \mathrm{i}$ during multiple-trial learning could be a key for triggering long-lasting gene expressiondependent phenomena involved in LTM formation.

The honeybee Apis mellifera is a well-established model to study the molecular basis of memory formation $[26,27]$. It presents important learning and memory capacities [27] and a brain accessible to different neurophysiological techniques, and genomic analysis is now possible since its genome has been sequenced [28].

To investigate whether $\mathrm{Ca}^{2+}$ is necessary and sufficient for LTM formation, we have used the Pavlovian appetitive conditioning of the proboscis extension reflex (PER) [29], in which bees learn to associate an odor conditioned stimulus (CS) with a sucrose unconditioned stimulus (US). In this assay, several memory phases have been described. In particular, a single conditioning trial leads only to short and mid-term memories, lasting about one day. However, multiple conditioning trials spaced by 10 minutes specifically lead to de novo protein synthesis-dependent LTM, lasting 72 hours or more [30]. Shortly after such training, an increase of $\mathrm{Ca}^{2+}$ responses was found in olfactory brain structures [31,32]. According to our hypothesis $\mathrm{Ca}^{2+}$ could be the primary trigger of LTM after multiple conditioning trials. Using pharmacological and caged compounds approaches to modify $\left[\mathrm{Ca}^{2+}\right]$ i during learning, we demonstrate that $\mathrm{Ca}^{2+}$ is both necessary and sufficient during acquisition for LTM formation.

\section{Results \\ Inhibition of $\left[\mathrm{Ca}^{2+}\right]$ increase during learning specifically impairs long-term memory formation}

Three conditioning trials with 10-min inter-trial intervals normally lead to high LTM performance at $72 \mathrm{~h}$. To test whether $\mathrm{Ca}^{2+}$ is necessary for LTM formation, we first evaluated the effect of 1,2-bis-(o-aminophenoxy)-ethane$\mathrm{N}, \mathrm{N}, \mathrm{N}$ ', N'-tetraacetic acid, tetraacetoxymethyl ester (BAPTA-AM), a membrane permeant $\mathrm{Ca}^{2+}$ chelator, injected $1 \mathrm{~h}$ before conditioning on memory performance at $72 \mathrm{~h}$. The results in Figure 1A (left panel) show that the percentage of conditioned responses (\%CR) increased similarly during conditioning in BAPTA-treated and control animals, indicating that BAPTA treatment does not affect acquisition performance. However, as shown on the histogram of Figure 1A (right panel, black bars), after 72 $\mathrm{h}$ the responses to the learned odor (CS) were significantly reduced in BAPTA-treated animals, relative to controls. To check whether memory was specific to the learned odor, we systematically compared performance to the CS and to a new odor in the two groups (Figure $1 \mathrm{~A}$, grey bars right panel). After $72 \mathrm{~h}$, while control animals responded significantly less to a new odor than to the CS, BAPTA-treated animals responded similarly to both stimuli. Furthermore, control and BAPTA-treated animals responded similarly to the new odor. All these data indicate that control animals have strong CS-specific LTM while BAPTA-treated animals present no such specific LTM.

Comparison of CS-specific responses (SR) (\% SR, corresponding to the proportion of individuals responding to the CS but not to the new odor) between groups confirmed the significant reduction of LTM performance after treatment with BAPTA-AM, relative to controls (Figure $1 \mathrm{~B})$. We also checked that memory performances at earlier retention times corresponding to earlier memory phases were not affected by treatment with BAPTA-AM. At $3 \mathrm{~h}$ and at $24 \mathrm{~h}$, SR were high and similar in treated and control groups. In addition, there was no effect on LTM per- 

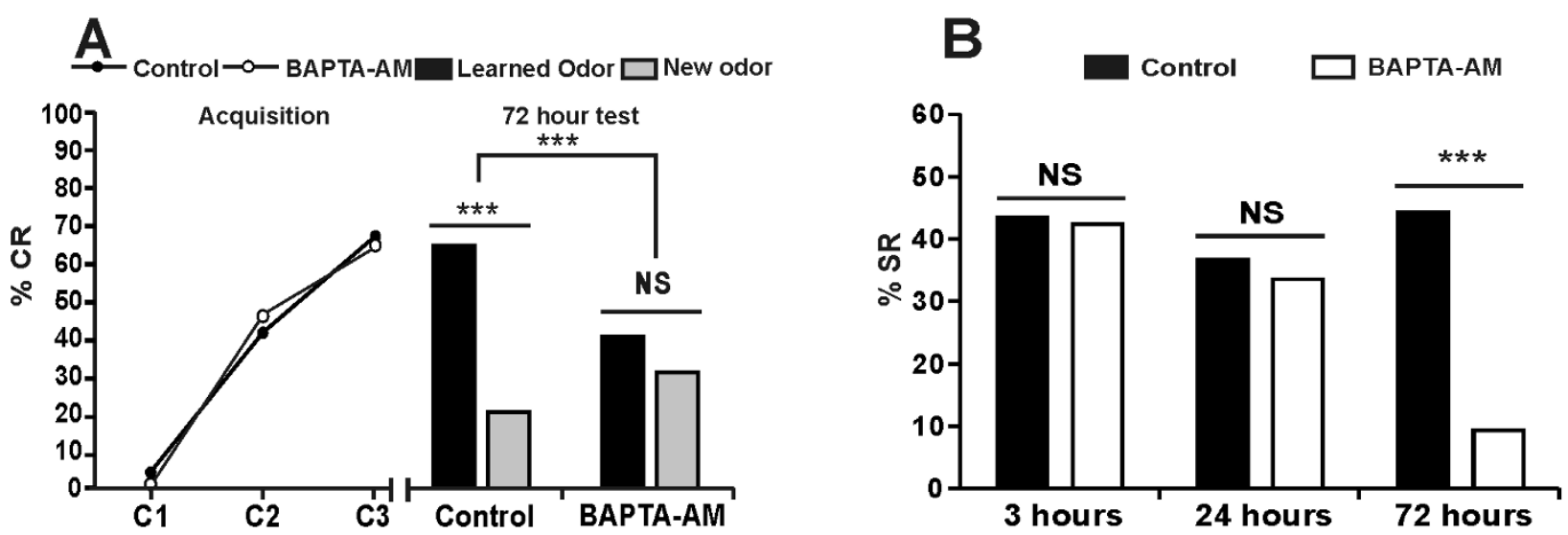

Figure I

Inhibition of $\left[\mathrm{Ca}^{2+}\right] \mathbf{i}$ increase using BAPTA-AM blocks long-term memory formation. Acquisition and retention performances following an injection of BAPTA-AM $500 \mu \mathrm{M}$, an intracellular $\mathrm{Ca}^{2+}$ chelator, or saline I $\mathrm{h}$ before training. A. Percentages of conditioned responses (\%CR) increase during the three conditioning trials $(\mathrm{Cl}, \mathrm{C} 2$ and $\mathrm{C} 3)$ for the control group ( $n=70, Q=60.0, P<0.00 \mathrm{I})$ and for the BAPTA-AM group $(n=85, Q=8 \mathrm{I} .0, P<0.00 \mathrm{I})$, without any difference between groups $(U=278.5, P=0.93)$. Response to the conditioned stimulus $(C S)$ after $72 \mathrm{~h}$ was significantly lower in the BAPTA-AM than in the control group $\left(\chi^{2}=9.1, P=0.0026\right)$. Moreover, bees responded significantly more to the CS than to the new odor in the control group $\left(\chi^{2}=24.3, P<0.00 \mathrm{I}\right)$ but not in the BAPTA-AM group $\left(\chi^{2}=2.0, P=0.15\right)$. Consequently, specific response proportion (\% individuals responding to the CS and not to the new odor) was significantly lower for BAPTA-AM than for control bees $\left(\chi^{2}=15.55, P<0.001\right)$. Furthermore, control and treated animals responded similarly to the new odor $\left(\chi^{2}=\right.$ 2.25, $P=0.13)$. B. The percentage of specific response (\% SR) at $3 \mathrm{~h}$ (Control: $n=125$; BAPTA-AM: $n=120)$ and $24 \mathrm{~h}($ Control: $n=1$ I2; BAPTA-AM: $n=1$ I 7) were not affected by treatment with BAPTA-AM (respectively: $\chi^{2}=0.65, P=0.42$ and $\chi^{2}=$ $0.43, P=0.5 \mathrm{I})$. The $\%$ SR presented at $72 \mathrm{~h}$ corresponds to the data of Figure IA. (***: $P<0.00 \mathrm{I}$, NS: non-significant).

formance when BAPTA-AM was injected $1 \mathrm{~h}$ after conditioning (Additional file 1). Thus in accordance with our hypothesis, a treatment that inhibits $\left[\mathrm{Ca}^{2+}\right]$ i increase during conditioning selectively impaired LTM performance, indicating that $\mathrm{Ca}^{2+}$ increase during learning is necessary for LTM formation.

\section{Increase of $\left[\mathrm{Ca}^{2+}\right]$ i specifically enhances long-term retention}

The previous experiment shows that $\mathrm{Ca}^{2+}$ is necessary to establish LTM, but is it sufficient? To answer this question we increased $\left[\mathrm{Ca}^{2+}\right] \mathrm{i}$ during one-trial conditioning, a training protocol normally inefficient to produce LTM [27]. Caffeine, which induces the release of $\mathrm{Ca}^{2+}$ from ryanodine-sensitive stores [33], was used to increase $\left[\mathrm{Ca}^{2+}\right] \mathrm{i}$ in the honeybee brain. As a prerequisite for this experiment, we confirmed with $\mathrm{Ca}^{2+}$ imaging experiments that an injection of caffeine $(20 \mathrm{mM})$ induces an increase of $\left[\mathrm{Ca}^{2+}\right]$ i. The $\mathrm{Ca}^{2+}$ signal was recorded during $60 \mathrm{~min}$ in three different olfactory structures (antennal lobe, alpha lobe of the mushroom bodies and lateral protocerebrum). After 10 min of recording, caffeine solution or saline was injected. As shown for the antennal lobe (Figure 2), and also for the two other recorded structures, caffeine application significantly increased $\left[\mathrm{Ca}^{2+}\right] \mathrm{i}$ during a 14-min time window, compared with saline application.
For behavioral experiments, caffeine was injected 20 min prior to one-trial conditioning. The caffeine-elicited $\mathrm{Ca}^{2+}$ release during one-trial conditioning induced a strong increase in responses to the CS at $72 \mathrm{~h}$, relative to saline injection (Figure 3A). This increased response reached a similar level to that obtained after three-trial conditioning. All groups responded significantly more to the learned odor than to the new odor. However, a significant response increase was also observed to the new odor in the caffeine group compared with the one-trial conditioning group. Such an increase is not surprising as there is some behavioral generalization from the learned odor to the new odor, and increasing memory for the learned odor through caffeine treatment may increase generalization responses to the novel odor [34]. As shown in Figure $3 \mathrm{~B}$ at $72 \mathrm{~h}$, caffeine treatment increased olfactory memory as the percentage of SR (\% SR) was significantly increased relative to one-trial conditioning control. Caffeine treatment had to be associated with a conditioning trial, as caffeine injected $20 \mathrm{~min}$ before a CS-only presentation did not lead to any LTM performance (Additional file 2).

In order to establish whether this increase affects memory before $72 \mathrm{~h}$, we compared the SR of caffeine-treated and control one-trial conditioning animals at $3 \mathrm{~h}$ and at $24 \mathrm{~h}$. In both cases, the CS-SR were similar, showing that the 


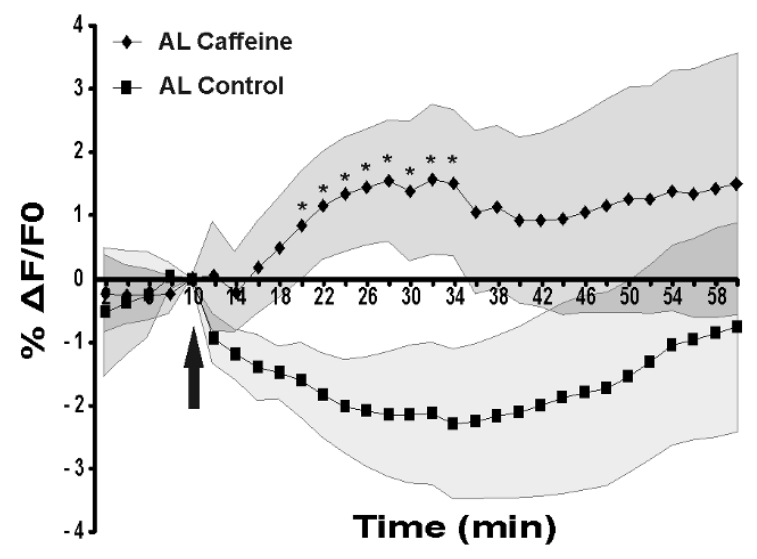

Figure 2

Caffeine induces a transient $\mathbf{C a}^{2+}$ increase in the honeybee brain. Relative fluorescence changes $(\% \Delta F / F 0)$ in the antennal lobe $(A L)$ after an application of $10 \mu \mathrm{l}$ of $20 \mathrm{mM}$ caffeine $(n=10)$ or saline $(n=7) 10$ min after the start of the recording (black arrow) and during 50 minutes. Between 10 and 24 min after caffeine application, the $\% \Delta \mathrm{F} / \mathrm{F} 0$ recorded for the caffeine animals is significantly higher than for the control animals. (*: $P<0.05, t$-test). Note that the drop in fluorescence observed in the saline recording is due to a change in the volume of solution between brain and objective.

effect of caffeine is specific to LTM formation. It should be noted that the drop in \% SR of control animals at $72 \mathrm{~h}$ represents natural memory decay for one-trial conditioning. Thus, the $\left[\mathrm{Ca}^{2+}\right] \mathrm{i}$ increase during one-trial conditioning induces LTM formation. A similar but only near-significant effect was observed on LTM performance when caffeine was injected immediately after one-trial conditioning. However, caffeine treatment had no effect when applied $1 \mathrm{~h}$ after one-trial conditioning (Additional file 1).

As caffeine has broader effects than just acting on $\mathrm{Ca}^{2+} \mathrm{lev}-$ els [35-37], a specific intracellular $\mathrm{Ca}^{2+}$ donor, the caged $O$-Nitrophenyl-ethyleneglycol-bis( $\beta$-aminoethyl)-

$\mathrm{N}, \mathrm{N}, \mathrm{N}^{\prime}, \mathrm{N}^{\prime}$-tetraacetoxymethyl ester (NP-EGTA-AM) was used to confirm the promnesic effect of $\mathrm{Ca}^{2+}$. As shown in Figure $4, \mathrm{Ca}^{2+}$ release by uncaging of NP-EGTA-AM $5 \mathrm{~min}$ before one-trial conditioning also induced a specific LTM increase at $72 \mathrm{~h}$. This increase was not found at $3 \mathrm{~h}$ or at $24 \mathrm{~h}$. Altogether, these data indicate that increasing $\left[\mathrm{Ca}^{2+}\right]$ i during one-trial conditioning leads to a specific olfactory LTM enhancement. Therefore, associated with one-trial, $\mathrm{Ca}^{2+}$ is sufficient for LTM formation.

\section{Long-term memory formation induced by an increase of $\left[\mathrm{Ca}^{2+}\right]$ i depends on protein synthesis}

LTM is dependent on a new wave of protein synthesis, required for the functional and structural synaptic modifications involved in long-term storage of information
$[6,30]$. To test whether the LTM formed after an increase in $\left[\mathrm{Ca}^{2+}\right] \mathrm{i}$ is dependent upon protein synthesis, we replicated the previous experiment in the presence of the transcription inhibitor, actinomycin-D (ACT-D). Bees were subjected to one-trial conditioning associated with the injection of caffeine $(20 \mathrm{mM})$ or saline solution, followed $3 \mathrm{~h}$ later either by an injection of ACT-D (experimental group) or saline solution (control group). These groups were then tested at $72 \mathrm{~h}$. As shown in Figure 5, performance in the one-trial group injected with caffeine was significantly higher than in the one-trial control group, reproducing the previous induction of LTM by caffeine. This increase of SR performance was totally erased in the corresponding experimental group injected with ACT-D, so that performance was equivalent to that in the one-trial control group. We also performed a control experiment with three-trial conditioning which received or not ACTD. Performances of this control three-trials conditioning group were strongly affected by ACT-D injection, as already described in the literature [38]. Thus, the increase in LTM performances in the caffeine-injected one-trial group is associated with de novo protein synthesis during consolidation.

\section{Discussion}

Here we show that: (i) treatment that inhibits $\left[\mathrm{Ca}^{2+}\right] \mathrm{i}$ increase during multiple-trial conditioning selectively impairs LTM performance; (ii) conversely, treatments that increase $\left[\mathrm{Ca}^{2+}\right] \mathrm{i}$ during one-trial conditioning greatly enhance LTM performance; and finally, (iii) as was the case for LTM produced by multiple-trial conditioning, the increased memory performance at long-term induced by an increase of $\left[\mathrm{Ca}^{2+}\right] \mathrm{i}$ depends on de novo protein synthesis. Altogether our data suggest that $\mathrm{Ca}^{2+}$ is both a necessary and a sufficient signal during olfactory conditioning for the formation of protein-dependent LTM.

The repetition of associative CS-US trials is thought to be the key for the formation of an odor-specific proteindependent LTM. Therefore, additional conditioning trials act as confirmations of the information gained during the first conditioning trial. A question that was left unanswered until now was which intracellular messengers were keeping track of the first associative trial? Our present results suggest that $\mathrm{Ca}^{2+}$ could play this role, priming neuronal units for subsequent trials and preparing for LTM formation. Indeed, we show that multiple trials in a context of reduced $\mathrm{Ca}^{2+}$ are treated by the nervous system as a single trial; conversely, a single trial in a context of increased $\mathrm{Ca}^{2+}$ mimics the effect of multiple trials. It should be noted that caffeine treatment had to be associated with a conditioning trial, as caffeine injected $20 \mathrm{~min}$ before a CS-only presentation did not lead to any LTM performance. Therefore, $\mathrm{Ca}^{2+}$ is sufficient for LTM formation only if an odor-sucrose association has taken place. This suggests that increased $\left[\mathrm{Ca}^{2+}\right] \mathrm{i}$ at the moment of a 

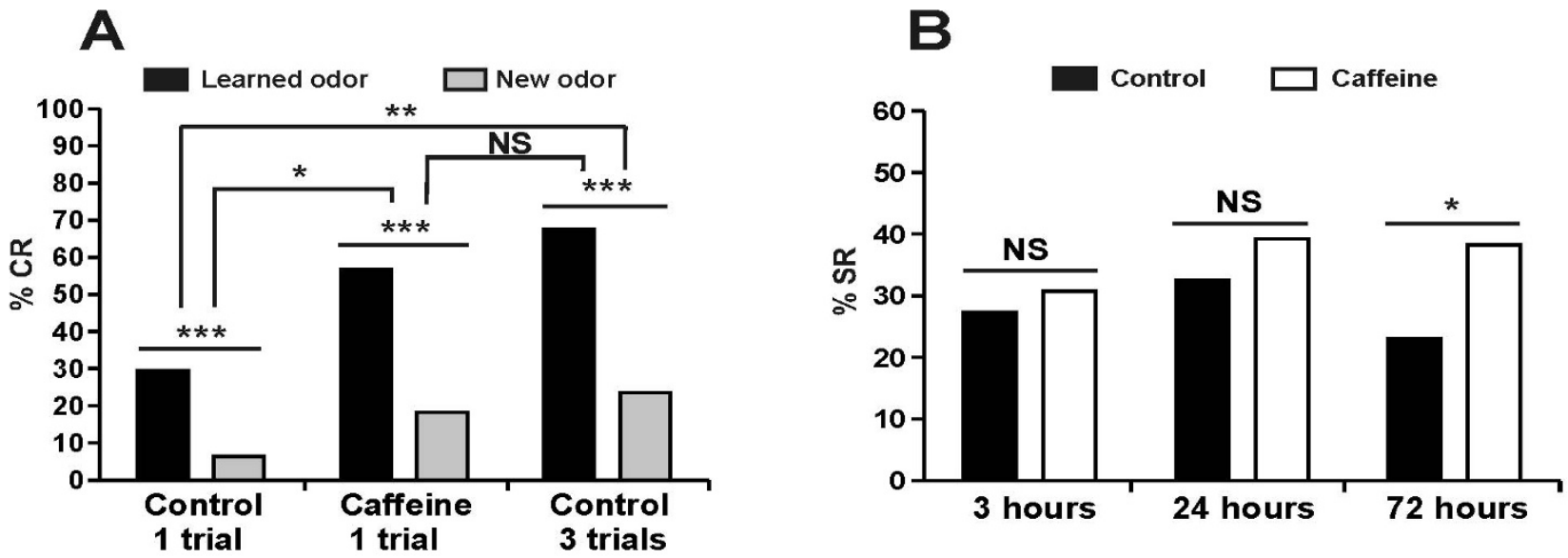

Figure 3

Increase of $\left[\mathrm{Ca}^{2+}\right] \mathrm{i}$ using caffeine triggers long-term memory formation. Retention performances following an injection of caffeine $(20 \mathrm{mM})$ or saline solution 20 min before one- or three-trial conditioning. A. Conditioned response (CR) to the learned odor at $72 \mathrm{~h}$ was significantly higher for the caffeine group $(n=60)$ than for the one-trial conditioning group $(n=$ 78) $\left(\chi^{2}=10.3, P=0.0013\right)$, but not different from the three-trial conditioning group $(n=68)\left(\chi^{2}=1.64, P=0.2\right)$. However, the response to the new odor was significantly different between the caffeine group and the one-trial conditioning $\left(\chi^{2}=4.7, P=\right.$ 0.03). Nevertheless, the caffeine group responded in the same way to the new odor than the three-trial conditioning group ( $\chi^{2}$ $=3.2, P=0.07)$. In addition, the control one-trial conditioning, the caffeine group and the control three-trial conditioning responded significantly more to the learned odor than to the new odor (respectively: McNemar $\chi^{2}=14.4, P<0.00$ I; McNemar $\chi^{2}=19.3, P<0.001$; McNemar $\left.\chi^{2}=23.3, P<0.001\right)$. Overall, specific response (SR) proportion of the caffeine group was significantly increased compared with those of the control one-trial conditioning $\left(\chi^{2}=3.9, P=0.049\right)$ and was not different from the control three-trial conditioning $\left(\chi^{2}=0.9, P=0.33\right)$. B. The percentage of specific responses $(\% \mathrm{SR})$ for caffeine and for the control one-trial conditioning at $3 \mathrm{~h}$ (Control: $n=95$; Caffeine: $n=78$ ) and at $24 \mathrm{~h}$ (Control: $n=77$; Caffeine: $n=84)$ were not affected by caffeine treatment (respectively: $\chi^{2}=0.2, P=0.62 ; \chi^{2}=0.8, P=0.37$ ). The $\%$ SR presented at $72 \mathrm{~h}$ corresponds to the data of Figure 3A (*: $P<0.05$, **: $P<0.01$, ***: $P<0.001$, NS: non-significant).

conditioning trial can act as the trigger for biochemical pathways that will lead to de novo protein synthesis, and to LTM.

We have found here that the modulation of $\left[\mathrm{Ca}^{2+}\right]$ i during learning affects specifically LTM while leaving learning and short-term memory (STM) intact. Similar results have been observed in rats in which blocking of the L-type voltage-gated $\mathrm{Ca}^{2+}$ channel with the antagonist verapamil also impaired LTM selectively and showed no effect on learning or STM [23]. All these data suggest that a threshold of $\left[\mathrm{Ca}^{2+}\right] \mathrm{i}$ level has to be reached during learning to trigger downstream pathways leading to de novo gene transcription required for LTM formation. It does not, however, mean that learning and STM do not rely at all on $\mathrm{Ca}^{2+}$. In fact, this might indicate that they require different ranges of $\left[\mathrm{Ca}^{2+}\right] \mathrm{i}$ than LTM. In any case, the memory formed before $24 \mathrm{~h}$ in honeybees is not dependent on de novo gene transcription [30].

Our conclusion that $\mathrm{Ca}^{2+}$ may be a memory trigger is further paralleled by an optical imaging study in Drosophila, which found increased $\mathrm{Ca}^{2+}$ responses in particular types of mushroom body intrinsic neurons ( $\alpha^{\prime} / \beta^{\prime}$ neurons) between 5 and 60 min after a single training cycle [39]. Therefore, our working model is that during acquisition, the first conditioning trial would increase $\mathrm{Ca}^{2+}$ levels in some parts of the olfactory network involved in memory formation, which would then trigger cascades, allowing LTM formation at the subsequent learning trials.

An important point is that $\mathrm{Ca}^{2+}$ alone does not contain the odor specificity for LTM. Indeed, in our experiments, drugs inducing $\left[\mathrm{Ca}^{2+}\right] \mathrm{i}$ increase were applied to the whole animal and likely affected all brain structures, yet the enhanced memory was odor specific. This is because odor specificity is ensured by mechanisms within the subset of neurons activated during the single CS-US trial, in particular the neurons that represent the CS in the olfactory network. This could correspond to subsets of antennal lobe neurons (projection neurons and/or local interneurons) or mushroom body neurons (Kenyon cells), which receive input from the US pathway (the ventral unpaired median neuron of the maxillary neuromere $1\left(\mathrm{VUM}_{\mathrm{mx} 1}\right)$ [40]) and are involved in olfactory learning and memory $[41,42]$.

We showed clearly that $\mathrm{Ca}^{2+}$ is critical for LTM. However, we have not determined the origin of $\mathrm{Ca}^{2+}$, that is, influx 


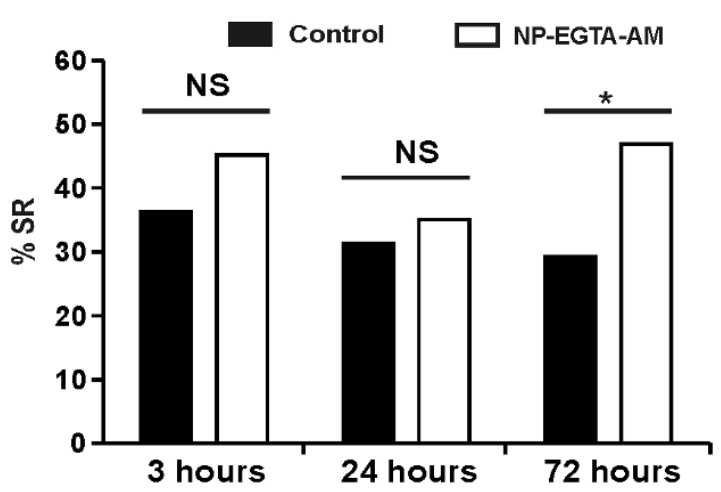

\section{Figure 4}

Increase of $\left[\mathrm{Ca}^{2+}\right] \mathrm{i}$ by uncaging of NP-EGTA-AM triggers long-term memory formation. Retention performances, as the percentage of specific response (\% SR, \% individuals responding to the conditioned stimulus and not to the new odor), following an injection of NP-EGTA-AM (20 $\mathrm{mM}$ ) or saline solution I $\mathrm{h}$ before one-trial conditioning. The SR of the NP-EGTA-AM $(n=64)$ group was significantly higher than the control $(n=72)$ at $72 \mathrm{~h}\left(\chi^{2}=4.53, P=0.033\right)$. However, at 3 h (Control: $n=66$; NP-EGTA-AM: $n=65$ ) and at $24 \mathrm{~h}$ (Control: $n=102$; NP-EGTA-AM: $n=1 \mathrm{II})$ the SR were no significantly different (respectively: $\chi^{2}=I . I, P=$ $\left.0.30 ; \chi^{2}=0.3, P=0.56\right)$. (*: $P<0.05$, NS: non-significant).

or release from internal stores. Neuropharmacological experiments have shown that nicotinic acetylcholine receptors are involved in the formation of LTM in bees [43]. These receptors could allow the entry of $\mathrm{Ca}^{2+}$ directly through their ion channel or indirectly after depolarization via voltage-gated $\mathrm{Ca}^{2+}$ channels. Moreover, octopamine released by the VUM-mx1 neuron in response to sucrose activates a receptor which can also induce an increase of [ $\left.\mathrm{Ca}^{2+}\right] \mathrm{i}[44]$. Thus, the convergence of these two $\mathrm{Ca}^{2+}$ influxes in olfactory cells could prime the system for LTM formation. In addition, our caffeine experiments suggest that $\mathrm{Ca}^{2+}$ released from internal stores may also participate in LTM formation. Indeed, caffeine induces the release of $\mathrm{Ca}^{2+}$ from ryanodine-sensitive stores [33] and several behavioral studies have demonstrated that an inhibition of ryanodine receptors impairs spatial $[45,46]$ and passive avoidance memory $[47,48]$. Other behavioral studies have shown evidence for the role of $\mathrm{Ca}^{2+}$ in the formation of LTM by blocking IP3-receptordependent intracellular $\mathrm{Ca}^{2+}$ stores [25].

Our work suggests that the increase of $\left[\mathrm{Ca}^{2+}\right]$ i during the first conditioning trial determines the fate of olfactory cells when the second trial is applied, inducing the cascades leading to LTM. This second trial can take place 10 min or even later after the first one. Disruption of $\mathrm{Ca}^{2+}$ homeostasis over such a long period of time could have

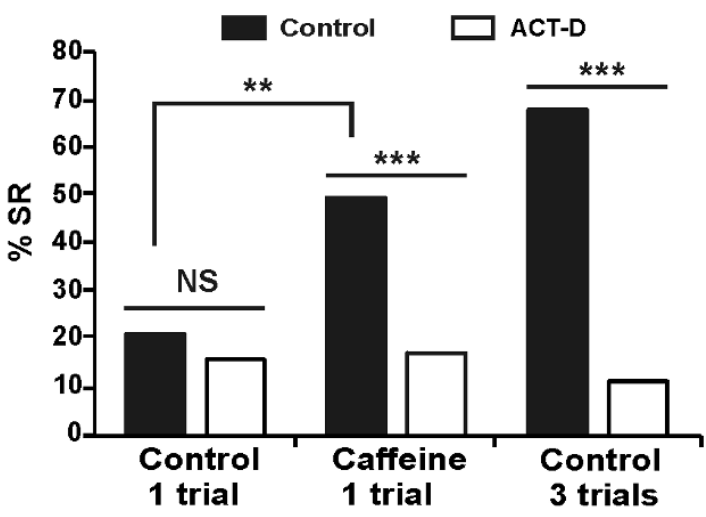

Figure 5

Long-term memory increase induced by $\mathrm{Ca}^{2+}$ is dependent on de novo gene transcription. Control bees are compared with bees that received an injection of actinomycin-D (ACT-D) $3 \mathrm{~h}$ after conditioning. In control bees (black bars), injection of caffeine 20 min before one-trial conditioning induced a significant increase in retention performance (percentage of specific response, \% SR, \% individuals responding to the conditioned stimulus and not to the new odor) at $72 \mathrm{~h}$, compared with bees which received a one-trial conditioning $\left(\chi^{2}=10.41, P=0.0013\right)$. This replicates the results shown in Figure 3. Bees which received three conditioning trials showed high long-term memory (LTM) performance, as usual. Injection of ACT-D (white bars) almost totally erased the promnesic effect of caffeine, so that there was no longer any difference between one-trial and one-trial plus caffeine bees. Bees of the caffeine group injected with ACT-D $(n=62)$ thus showed a significant decrease of SR compared with control bees $(n=6 I)\left(\chi^{2}=16.62, P<0.00 I\right)$. No difference appears for the control one trial conditioning $\left(\chi^{2}=0.24, P=0.62\right.$; Control: $n=64$; ACT-D: $\left.n=69\right)$. LTM produced by three-trial conditioning was also utterly erased $\left(\chi^{2}=40.29, P<0.001\right.$; control: $n=63$; ACT-D: $\left.n=70\right)$.

detrimental effects on the survival of the cells. Therefore, we favor the hypothesis that an early and transient $\mathrm{Ca}^{2+}$ signal is sufficient to prime olfactory cells for the formation of LTM, and that a relay bridges the gap between associative trials. One possible hypothesis is that $\mathrm{Ca}^{2+}$ dependent signaling pathways could be this relay. For instance, the involvement of CaMKII, a $\mathrm{Ca}^{2+} / \mathrm{CaM}$-activated kinase, in LTM formation has been demonstrated in several studies [49]. The CaMKII has important molecular regulatory features that make it ideally suited for decoding cytosolic $\mathrm{Ca}^{2+}$ signals and translating these signals into the appropriate cellular response via phosphorylation [50]. Its main functional property is the ability for autophosphorylation. This alters the enzyme such that its activity becomes independent of $\mathrm{Ca}^{2+} / \mathrm{CaM}$ binding [50] and can mediate $\mathrm{Ca}^{2+}$-induced signaling on a time scale of several minutes, possibly bridging the gap between conditioning 
trials. Other molecular cascades, such as the NO-cyclic guanine monophosphate (NO-cGMP) or the cAMP-protein kinase A (CAMP-PKA) pathways which have also been shown to be critical for LTM formation [10,51], could play a similar role, since both NO synthase (NOS) and PKA are highly dependent on $\mathrm{Ca}^{2+}$. Furthermore, CaMKII and PKA, for example, can also activate the transcription factor CREB [52] which mediates immediate-early gene transcription [53].

Despite the possible role of $\mathrm{Ca}^{2+-d e p e n d e n t ~ s i g n a l i n g ~}$ pathways described above, $\mathrm{Ca}^{2+}$ can also invade the nucleus to play a more direct role in gene transcription required for LTM formation [54]. Indeed, $\mathrm{Ca}^{2+}$ can act directly and rapidly on gene expression through the cisregulatory element, downstream regulatory element which has been involved in stimulation-transcription coupling mechanisms [55].

Multiple trial conditioning, mediated by $\mathrm{Ca}^{2+}$-dependent pathways as described above, will lead to de novo protein synthesis. As the honeybee genome sequence is available [28] and microarrays of honeybee genes are now accessible (Roy J Carver Biotechnology Center, Illinois, USA), future research will explore $\mathrm{Ca}^{2+}$-dependent genes and their involvement in LTM formation.

\section{Conclusion}

Our work shows that $\mathrm{Ca}^{2+}$ is both a necessary and a sufficient signal during conditioning for the formation of protein-dependent LTM. As intracellular $\mathrm{Ca}^{2+}$ increase is one of the earliest events following neuronal activation during learning, our results suggest $\mathrm{Ca}^{2+}$ could be an early trigger of the cellular cascades leading to de novo gene expressiondependent LTM formation. We propose that $\mathrm{Ca}^{2+}$ plays the role of a switch between short- and long-term storage of learned information.

\section{Methods}

\section{Animals}

Honeybees (Apis mellifera ligustica) were caught at the hive entrance and were placed into standard harnesses. They were then fed with $5 \mu \mathrm{l}$ of $50 \%$ sucrose solution and kept for $3 \mathrm{~h}$ before conditioning.

\section{Classical olfactory conditioning}

Olfactory conditioning of the PER [29] was carried out as described elsewhere [56]. Bees were either subjected to a single conditioning trial (4 sec odor CS, $3 \mathrm{sec}$ sucrose US to antennae and proboscis, 1 sec overlap), or to three conditioning trials with $10 \mathrm{~min}$ inter-trial intervals. After conditioning, bees were kept in a dark, humid container at room temperature $\left(20\right.$ to $25^{\circ} \mathrm{C}$ ) until retrieval test at $3 \mathrm{~h}$, $24 \mathrm{~h}$ or $72 \mathrm{~h}$. These retrieval tests were carried out on separate groups of bees to avoid the possible consequences of multiple testing on the same animals. Bees were fed twice a day with a droplet of $50 \%$ sucrose solution except on the morning of the retrieval tests. During these tests, bees were exposed in extinction conditions to the CS and to a new odor in order to check whether the formed memory was CS-specific. All experiments were carried out in a balanced fashion with two odors A and B as CS and new odor, respectively. Thus, every experimental day, A was the CS for half the bees, and B for the other half. We chose for A and B pairs of odors that are well differentiated by bees (2-hexanol vs 1-nonanol or 1-hexanol vs 1-nonanol [34]). The US was $50 \%$ sucrose.

\section{Chemicals}

The drugs were injected with a volume of $1 \mu$ into the thorax for pharmacological experiments, or into the head hemolymph for uncaging experiments. For $\mathrm{Ca}^{2+}$-blocking experiments, the intracellular $\mathrm{Ca}^{2+}$ chelator (BAPTA-AM) (Molecular Probes, OR, USA) at $500 \mu \mathrm{M}$ was injected $1 \mathrm{~h}$ prior to conditioning, corresponding to the necessary time for drug esterification. In a control experiment, the injection was done $1 \mathrm{~h}$ after conditioning. For intracellular $\mathrm{Ca}^{2+}$-increase experiments, two treatments were done. Caffeine, allowing liberation from intracellular $\mathrm{Ca}^{2+}$ stores via ryanodine receptors, was applied at $20 \mathrm{mM} 20$ min before conditioning or, for the control experiments, just after or $1 \mathrm{~h}$ after conditioning. Another control experiment was carried out by injecting $20 \mathrm{mM}$ caffeine $20 \mathrm{~min}$ before a CS-only presentation. In addition, intracellular $\mathrm{Ca}^{2+}$ was released experimentally (see photolysis below) using the caged $\mathrm{Ca}^{2+}$ donor O-Nitrophenyl-ethyleneglycol-bis( $\beta$-aminoethyl)-N,N,N',N'-tetraacetoxymethyl

ester (NP-EGTA-AM; Molecular Probes, OR, USA) at 20 $\mathrm{mM}$, injected $1 \mathrm{~h}$ before conditioning. To inhibit transcription, ACT-D at $1.5 \mathrm{mM}$ was injected $3 \mathrm{~h}$ after conditioning.

Caffeine was diluted in bee saline $(130 \mathrm{mM} \mathrm{NaCl}, 6 \mathrm{mM}$ $\mathrm{KCl}, 4 \mathrm{mM} \mathrm{MgCl}, 5 \mathrm{mM} \mathrm{CaCl}_{2}, 160 \mathrm{mM}$ sucrose, $25 \mathrm{mM}$ glucose and $10 \mathrm{mM}$ HEPES, $\mathrm{pH}$ 6.7). Other drugs were diluted in saline with $0.5 \%$ dimethylsulfoxyde (DMSO) for NP-EGTA-AM or $0.1 \%$ for BAPTA-AM, except for ACT$\mathrm{D}$ which was diluted in phosphate-buffered saline. Control groups received vehicle injections containing the same DMSO concentration as the corresponding experimental groups. For the conditioning, the odors used were 1-hexanol, 2-hexanol (Fluka, Germany) and 1-nonanol (Sigma-Aldrich, France).

For $\mathrm{Ca}^{2+}$ measurements, we used $33 \mu \mathrm{M}$ calcium green 2 acetoxymethyl ester (2AM) (Molecular Probes, OR, USA), dissolved in bee saline containing $2.5 \%$ pluronic acid F127 (Molecular Probes, OR, USA). All intracellular $\mathrm{Ca}^{2+}$ probes (with AM component) are currently used for maximum efficiency $1 \mathrm{~h}$ after application for in vivo $\mathrm{Ca}^{2+}$ imag- 
ing $[57,58]$ or for in vitro experiments [59]. All materials were obtained from Sigma-Aldrich (France) except otherwise stated.

\section{Flash photolysis of caged compounds}

One hour after injection of the caged compound, bees were exposed to ultra violet (UV) light for $1 \mathrm{~min}$ and conditioned 5 min afterwards. To carry out UV photolysis, a custom optical system was built, composed of a $100 \mathrm{~W}$ mercury arc flash lamp, a UV transmitting fused-silica condenser, and a shutter. The location and focusing of the UV spot were adjusted so that light was homogeneous on the whole brain. The optimum uncaging conditions were $800 \mu \mathrm{W} / \mathrm{cm}^{2} / \mathrm{min}$ at $360 \mathrm{~nm}$, determined with a UV meter (UVP, San Gabriel, California, USA).

\section{Calcium imaging}

In vivo $\mathrm{Ca}^{2+}$ imaging recordings with calcium green $2 \mathrm{AM}$ were carried out as described elsewhere [58] with some modifications. Fluorescence was recorded for $60 \mathrm{~min}$ at a rate of 1 frame every $6 \mathrm{sec}$, with a $4 \times 4$ binning and $50 \mathrm{~ms}$ integration time. Ten minutes after the start of the experiment, $10 \mu \mathrm{l}$ of caffeine $(20 \mathrm{mM})$ or saline were applied onto the brain. Relative fluorescence changes were analyzed on three regions of interest corresponding to three olfactory brain structures (antennal lobe, alpha lobe of the mushroom bodies and lateral protocerebral lobe).

\section{Data analysis}

All experiments were performed with two odors A and B in a balanced protocol (see classical olfactory conditioning, above). As no significant effect of the specific odor used as CS (A versus B) appeared in any of the groups, data with both odors were pooled. Acquisition performance within each group was tested using Cochran's Q test. Possible differences of acquisition performance between groups were tested with Mann-Whitney $U$ tests. For retrieval tests, we compared within groups the difference of responses between the CS and the new odor with McNemar tests. Differences in CS or new odor responses between groups were assessed using $\chi^{2}$ tests.

As we systematically tested the CS and a new odor, we also compared memory specificity for the CS between groups. We calculated the proportions of individuals responding to the CS and not to the new odor, later termed 'Specific Response proportion' (\% SR). These proportions were compared between groups using $\chi^{2}$ tests. To keep a conservative decision threshold, only significant increases of $\%$ SR through drug application were considered as memory enhancement.

In $\mathrm{Ca}^{2+}$ imaging experiments, relative fluorescence changes $(\% \Delta \mathrm{F} / \mathrm{F} 0)$ are represented in 2 -min windows (average of 20 frames), with the 2-min window before drug application as reference. The possible difference in $\mathrm{Ca}^{2+}$ levels between caffeine and control groups was tested at each time window using a paired $t$-test.

\section{Abbreviations}

AC: adenylate cyclase; ACT-D: actinomycin-D; BAPTAAM: $\quad$ 1,2-bis-(o-aminophenoxy)-ethane-N,N,N',N'tetraacetic acid tetraacetoxymethyl ester; $\mathrm{Ca}^{2+}$ : calcium; $\left[\mathrm{Ca}^{2+}\right]$ i: intracellular calcium concentration; $\mathrm{Ca}^{2+} / \mathrm{CaM}-$ KII: calcium/calmodulin-dependent kinase II; CaM: calmodulin; CAMP: cyclic adenosine monophosphate; CR: conditioned responses; CREB: cyclic adenosine monophosphate responsive element binding protein; CS: conditioned stimulus; DMSO: dimethylsulfoxyde; LTM: longterm memory; NO: nitric oxide; NP-EGTA-AM: O-Nitrophenyl-ethyleneglycol-bis( $\beta$-aminoethyl)-N,N,N',N'tetraacetoxymethyl ester; PER: proboscis extension reflex; PKA: protein kinase A; SR: specific responses; US: unconditioned stimulus; UV: ultra violet; $\operatorname{VUM}_{\mathrm{mx} 1}$ : ventral unpaired median neuron of the maxillary neuromere 1 .

\section{Authors' contributions}

EP carried out most of the experiments, performed the statistical analysis and participated in its design, and contributed to the draft of the manuscript. VR, IN, CL, MM and JCS conceived the study, participated in its design and coordination and helped to draft the manuscript. YM carried out part of the behavioral experiments. JCS helped to perform the statistical analysis. All authors read and approved the final manuscript.

\section{Additional material}

\section{Additional file 1}

Control injections of BAPTA-AM and caffeine after conditioning. Effect of drug injection on long-term memory (LTM) performance (at 72 $h)$, plotted as the difference $(\Delta S R)$ of the percentage of specific response (\% individuals responding to the conditioned stimulus and not to the new odor) between treated and control groups. A negative value indicates a memory disruption while a positive value indicates a memory improvement. Thus, bees injected with a Ca ${ }^{2+}$ chelator, BAPTA-AM $1 \mathrm{~h}$ before a three-trial conditioning, show a strong and significant memory disruption (see Figure 1 and main text). A control group injected $1 \mathrm{~h}$ after conditioning with BAPTA-AM shows only a weak and non-significant decrease of LTM performance compared with controls $\left(\chi^{2}=0.49, \mathrm{P}=0.48\right.$; Control: $\mathrm{n}=56 ;$ BAPTA-AM: $\mathrm{n}=50$ ). Conversely, bees injected with caffeine, allowing a release of $\mathrm{Ca}^{2+}$ from internal stores, 20 min before a single conditioning trial, show improved LTM performance (see Figure 3 and main text). In Control experiments, when caffeine is injected immediately after the conditioning trial ( $0 \mathrm{~min})$, a near-significant increase of LTM performance is observed ( $\chi^{2}=0.49, \mathrm{P}=0.078 ;$ Control: $\mathrm{n}=70 ;$ Caffeine: $\mathrm{n}$ $=80)$. However, injection $1 \mathrm{~h}$ after the conditioning trial does not show any memory increase $\left(\chi^{2}=0, \mathrm{P}=0.98 ;\right.$ Control: $\mathrm{n}=39$; Caffeine: $\mathrm{n}=$ 47) $\left(^{*}: \mathrm{P}<0.05,{ }^{* *}: \mathrm{P}<0.001,\left({ }^{*}\right)\right.$ : nearly significant, NS: non-significant).

Click here for file

[http://www.biomedcentral.com/content/supplementary/17417007-7-30-S1.tiff] 


\section{Additional file 2}

Control for the conditioned stimulus-unconditioned stimulus association needed for the promnesic caffeine effect. Retention performances at $72 \mathrm{~h}$, as the percentage of specific response (\% SR, \% individuals responding to the conditioned stimulus (CS) and not to the new odor), between controls and bees injected with caffeine $20 \mathrm{~min}$, before one conditioning trial (CS + unconditioned stimulus (US)) or a CS-alone trial. The results of the CS + US group were presented in details in Figure 3. In the CSalone situation, neither control nor caffeine-injected bees show any remarkable long-term memory $(L T M)$ performance $\left(\chi^{2}=0, \mathrm{P}=0.97\right.$; Control: $\mathrm{n}=39$; Caffeine: $\mathrm{n}=40$ ). Caffeine therefore has no effect without a full CS-US conditioning trial. ( ${ }^{*}: \mathrm{P}<0.05$, NS: non-significant). Click here for file

[http://www.biomedcentral.com/content/supplementary/17417007-7-30-S2.tiff]

\section{Acknowledgements}

This work was supported by the Centre National de la Recherche Scientifique (CNRS) and the University Paul Sabatier (Toulouse, France). EP is the recipient of a grant from the Ministère de la Recherche et de la Technologie (MRT). YM is a recipient of a grant from Fyssen Foundation. We thank $L$ Scheunemann, K Richetin, P Gourbeyre, F Giraud and L Simonin for technical assistance.

\section{References}

I. Martin SJ, Morris RG: New life in an old idea: the synaptic plasticity and memory hypothesis revisited. Hippocampus 2002, 12:609-636.

2. Lynch MA: Long-term potentiation and memory. Physiol Rev 2004, 84:87-136.

3. Bailey $\mathrm{CH}$, Bartsch D, Kandel ER: Toward a molecular definition of long-term memory storage. Proc Natl Acad Sci USA 1996 , 93:13445-13452.

4. Kandel ER: The molecular biology of memory storage: a dialog between genes and synapses. Biosci Rep 200I, 21:565-6II.

5. Dudai $Y$ : Molecular bases of long-term memories: a question of persistence. Curr Opin Neurobiol 2002, 12:211-216.

6. Davis HP, Squire LR: Protein synthesis and memory: a review. Psychol Bull 1984, 96:518-559.

7. Hernandez PJ, Abel T: The role of protein synthesis in memory consolidation: progress amid decades of debate. Neurobiol Learn Mem 2008, 89:293-3II.

8. Dudai Y, Corfas G, Hazvi S: What is the possible contribution of Ca2+-stimulated adenylate cyclase to acquisition, consolidation and retention of an associative olfactory memory in Drosophila. J Comp Physiol [A] 1988, 162:101-109.

9. Schacher S, Castellucci VF, Kandel ER: CAMP evokes long-term facilitation in Aplysia sensory neurons that requires new protein synthesis. Science 1988, 240:1667-1669.

10. Muller U: Inhibition of nitric oxide synthase impairs a distinct form of long-term memory in the honeybee, Apis mellifera. Neuron 1996, 16:541-549.

1I. Mansuy IM, Mayford M, Jacob B, Kandel ER, Bach ME: Restricted and regulated overexpression reveals calcineurin as a key component in the transition from short-term to long-term memory. Cell 1998, 92:39-49.

12. Schwarzel M, Muller U: Dynamic memory networks: dissecting molecular mechanisms underlying associative memory in the temporal domain. Cell Mol Life Sci 2006, 63:989-998.

13. Matsumoto $Y$, Unoki S, Aonuma H, Mizunami M: Critical role of nitric oxide-cGMP cascade in the formation of CAMP. dependent long-term memory. Learn Mem 2006, I 3:35-44.

14. Irvine EE, von Hertzen LS, Plattner F, Giese KP: alphaCaMKII autophosphorylation: a fast track to memory. Trends Neurosci 2006, 29:459-465.
15. Mons N, Guillou JL, Jaffard R: The role of Ca2+/calmodulin-stimulable adenylyl cyclases as molecular coincidence detectors in memory formation. Cell Mol Life Sci 1999, 55:525-533.

16. Zars T, Wolf R, Davis R, Heisenberg M: Tissue-specific expression of a type I adenylyl cyclase rescues the rutabaga mutant memory defect: in search of the engram. Learn Mem 2000, $7:|8-3|$

17. Poser S, Storm DR: Role of Ca2+-stimulated adenylyl cyclases in LTP and memory formation. Int J Dev Neurosci 200I, 19:387-394.

18. Ferguson GD, Storm DR: Why calcium-stimulated adenylyl cyclases? Physiology (Bethesda) 2004, 19:27I-276.

19. Lisman JE: Three Ca2+ levels affect plasticity differently: the LTP zone, the LTD zone and no man's land. J Physiol 200I, 532:285.

20. Reymann KG, Frey JU: The late maintenance of hippocampal LTP: requirements, phases, 'synaptic tagging', 'late-associativity' and implications. Neuropharmacology 2007, 52:24-40.

21. Quevedo J, Vianna M, Daroit D, Born AG, Kuyven CR, Roesler R, Quillfeldt JA: L-type voltage-dependent calcium channel blocker nifedipine enhances memory retention when infused into the hippocampus. Neurobiol Learn Mem 1998, 69:320-325.

22. Blackwell KT, Alkon DL: Ryanodine receptor modulation of in vitro associative learning in Hermissenda crassicornis. Brain Res 1999, 822: I| 4-125

23. Bauer EP, Schafe GE, LeDoux JE: NMDA receptors and L-type voltage-gated calcium channels contribute to long-term potentiation and different components of fear memory formation in the lateral amygdala. J Neurosci 2002, 22:5239-5249.

24. Woodside BL, Borroni AM, Hammonds MD, Teyler TJ: NMDA receptors and voltage-dependent calcium channels mediate different aspects of acquisition and retention of a spatial memory task. Neurobiol Learn Mem 2004, 8 I:I05-I I4.

25. Baker KD, Edwards TM, Rickard NS: Inhibition of $\mathbf{m G l u R I}$ and IP3Rs impairs long-term memory formation in young chicks. Neurobiol Learn Mem 2008, 90:269-274.

26. Menzel R, Muller U: Learning and memory in honeybees: from behavior to neural substrates. Annu Rev Neurosci 1996, 19:379-404.

27. Menzel R: Searching for the memory trace in a mini-brain, the honeybee. Learn Mem 200I, 8:53-62.

28. The Honeybee Genome Sequencing Consortium: Insights into social insects from the genome of the honeybee Apis mellifera. Nature 2006, 443:93I-949.

29. Bitterman ME, Menzel R, Fietz A, Schafer S: Classical conditioning of proboscis extension in honeybees (Apis mellifera). J Comp Psychol 1983, 97:107-119.

30. Menzel R, Manz G, Menzel R, Greggers U: Massed and spaced learning in honeybees: the role of CS, US, the intertrial interval, and the test interval. Learn Mem 200I, 8:198-208.

31. Faber T, Joerges J, Menzel R: Associative learning modifies neural representations of odors in the insect brain. Nat Neurosci 1999, 2:74-78.

32. Faber T, Menzel R: Visualizing mushroom body response to a conditioned odor in honeybees. Naturwissenschaften 2001, 88:472-476

33. McPherson PS, Kim YK, Valdivia H, Knudson CM, Takekura H, Franzini-Armstrong $\mathrm{C}$, Coronado $\mathrm{R}$, Campbell KP: The brain ryanodine receptor: a caffeine-sensitive calcium release channel. Neuron 1991, 7:17-25

34. Guerrieri F, Schubert M, Sandoz JC, Giurfa M: Perceptual and neural olfactory similarity in honeybees. PLoS Biol 2005, 3:e60.

35. Vaugeois JM: Signal transduction: positive feedback from coffee. Nature 2002, 41 8:734-736.

36. Lorist MM, Tops M: Caffeine, fatigue, and cognition. Brain Cogn 2003, 53:82-94

37. Kucharski R, Maleszka R: Microarray and real-time PCR analyses of gene expression in the honeybee brain following caffeine treatment. J Mol Neurosci 2005, 27:269-276.

38. Wustenberg D, Gerber B, Menzel R: Short communication: longbut not medium-term retention of olfactory memories in honeybees is impaired by actinomycin $D$ and anisomycin. Eur J Neurosci 1998, I 0:2742-2745.

39. Wang Y, Mamiya A, Chiang AS, Zhong Y: Imaging of an early memory trace in the Drosophila mushroom body. I Neurosci 2008, 28:4368-4376. 
40. Hammer M: An identified neuron mediates the unconditioned stimulus in associative olfactory learning in honeybees. Nature 1993, 366:59-63.

4I. Hammer M, Menzel R: Multiple sites of associative odor learning as revealed by local brain microinjections of octopamine in honeybees. Learn Mem 1998, 5:|46-156.

42. Farooqui T, Robinson K, Vaessin H, Smith BH: Modulation of early olfactory processing by an octopaminergic reinforcement pathway in the honeybee. I Neurosci 2003, 23:5370-5380.

43. Gauthier M, Dacher M, Thany SH, Niggebrugge C, Deglise P, Kljucevic $P$, Armengaud C, Grunewald B: Involvement of alpha-bungarotoxin-sensitive nicotinic receptors in long-term memory formation in the honeybee (Apis mellifera). Neurobiol Learn Mem 2006, 86: I64-174.

44. Grohmann L, Blenau W, Erber J, Ebert PR, Strunker T, Baumann A Molecular and functional characterization of an octopamine receptor from honeybee (Apis mellifera) brain. J Neurochem 2003, 86:725-735

45. Ohnuki T, Nomura Y: I-[[[5-(4-Nitrophenyl)-2-furanyl]methylene]imino]-2,4-imidazolidinedione (dantrolene), an inhibitor of intracellular $\mathrm{Ca2}+$ mobilization, impairs avoidance performance and spatial memory in mice. Biol Pharm Bull 1996 19:1038-1040.

46. Balschun D, Wolfer DP, Bertocchini F, Barone V, Conti A, Zuschratter W, Missiaen L, Lipp HP, Frey JU, Sorrentino V: Deletion of the ryanodine receptor type 3 (RyR3) impairs forms of synaptic plasticity and spatial learning. Embo J 1999, I 8:5264-5273.

47. Salinska EJ, Bourne RC, Rose SP: Long-term memory formation in the chick requires mobilization of ryanodine-sensitive intracellular calcium stores. Neurobiol Learn Mem 200I, 75:293-302

48. Edwards TM, Rickard NS: Pharmaco-behavioural evidence indicating a complex role for ryanodine receptor calcium release channels in memory processing for a passive avoidance task. Neurobiol Learn Mem 2006, 86: I-8.

49. Cammarota M, Bevilaqua LR, Medina JH, Izquierdo I: ERKI/2 and CaMKII-mediated events in memory formation: is $5 \mathrm{HT}$ regulation involved? Behav Brain Res 2008, I 95: I20-। 28.

50. Soderling TR, Chang B, Brickey D: Cellular signaling through multifunctional $\mathbf{C a 2 + / c a l m o d u l i n - d e p e n d e n t ~ p r o t e i n ~ k i n a s e ~}$ II. J Biol Chem 2001, 276:3719-3722.

51. Muller U: Prolonged activation of cAMP-dependent protein kinase during conditioning induces long-term memory in honeybees. Neuron 2000, 27:I59-I68.

52. Shaywitz Al, Greenberg ME: CREB: a stimulus-induced transcription factor activated by a diverse array of extracellular signals. Annu Rev Biochem 1999, 68:821-861.

53. Greenberg ME, Thompson MA, Sheng M: Calcium regulation of immediate early gene transcription. J Physiol Paris 1992, 86:99-108.

54. Berridge M]: Neuronal calcium signaling. Neuron I998, 2 I: I3-26.

55. Carrion AM, Link WA, Ledo F, Mellstrom B, Naranjo JR: DREAM is a Ca2+-regulated transcriptional repressor. Nature 1999, 398:80-84.

56. Guerrieri F, Lachnit H, Gerber B, Giurfa M: Olfactory blocking and odorant similarity in the honeybee. Learn Mem 2005, I 2:86-95.

57. Galizia CG, Vitter R: Optical methods for analyzing odorevoked activity in the insect brain. In Advances in Insect Sensory Neuroscience Edited by: Christensen TA. Boca Raton: CRC Press; 2005:349-392

58. Sandoz JC: Odour-evoked responses to queen pheromone components and to plant odours using optical imaging in the antennal lobe of the honey bee drone Apis mellifera $L$. J Exp Biol 2006, 209:3587-3598.

59. Kunjilwar KK, Fishman HM, Englot DJ, O'Neil RG, Walters ET: Longlasting hyperexcitability induced by depolarization in the absence of detectable Ca2+ signals. I Neurophysiol 2009 , | $01: 1351-1360$
Publish with Bio Med Central and every scientist can read your work free of charge

"BioMed Central will be the most significant development for disseminating the results of biomedical research in our lifetime. "

Sir Paul Nurse, Cancer Research UK

Your research papers will be:

- available free of charge to the entire biomedical community

- peer reviewed and published immediately upon acceptance

- cited in PubMed and archived on PubMed Central

- yours - you keep the copyright

Submit your manuscript here:

http://www.biomedcentral.com/info/publishing_adv.asp
BioMedcentral 